\title{
Enhanced Antitumor Efficacy of Macrophage-Mediated Egg Yolk Lipid-Derived Delivery System Against Breast Cancer [Corrigendum]
}

\author{
Lv Y, Jun Y, Tang $\mathrm{Z}$, et al. Int $J$ Nanomedicine. \\ 2020;15:10075-10084. \\ The authors apologize for this error and advise it does not \\ affect the results of the paper.
}

The authors have advised due to an error at the time of figure assembly, Figure 5C on page 10082 is incorrect. The correct Figure 5 is shown below.

A
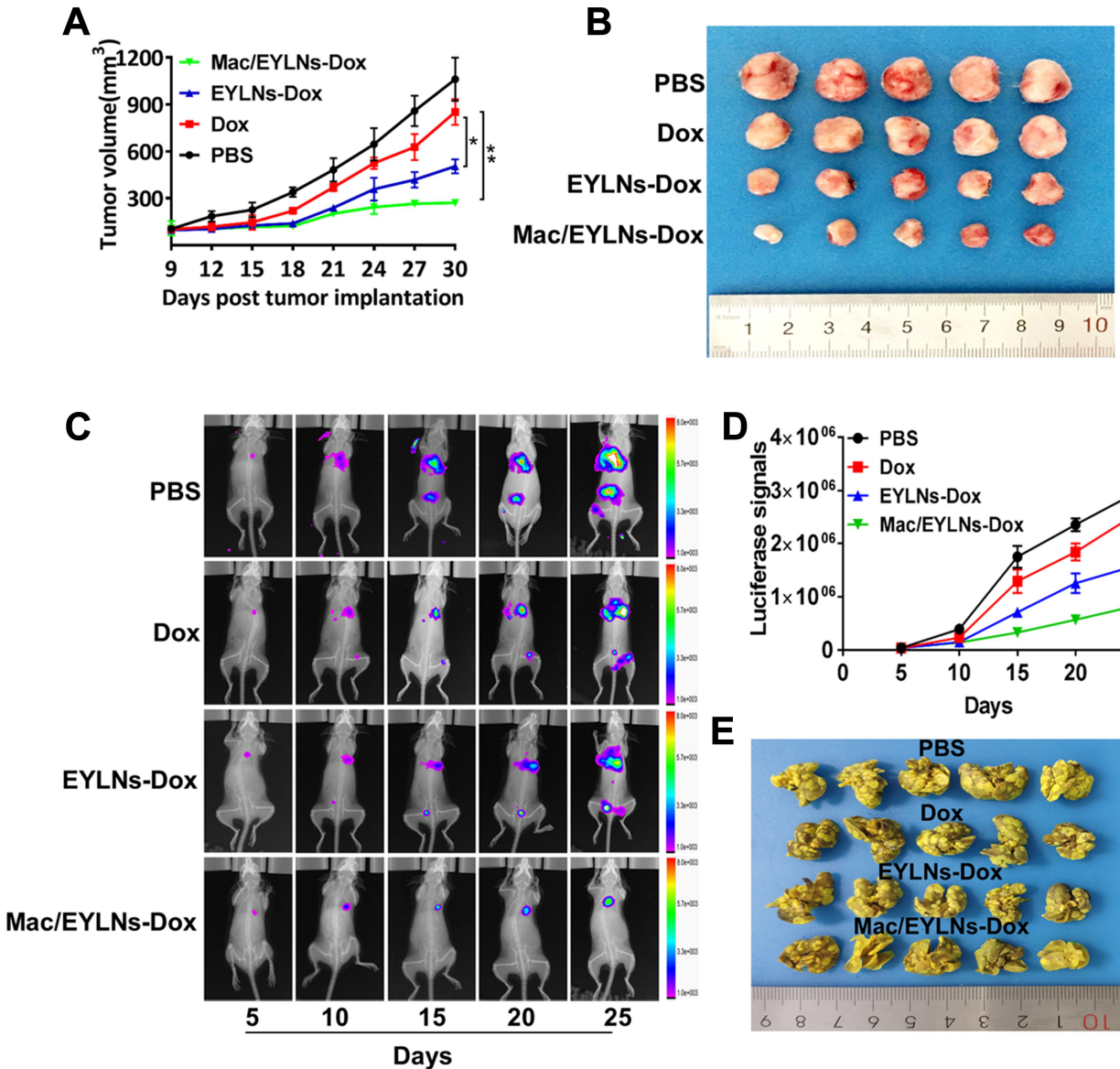

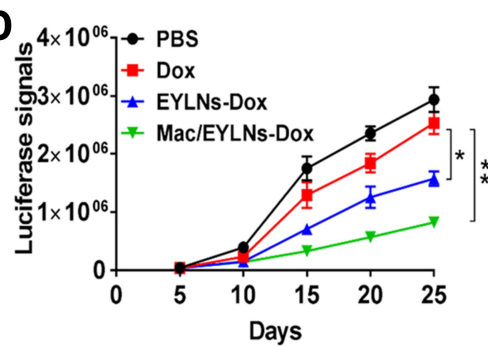

E

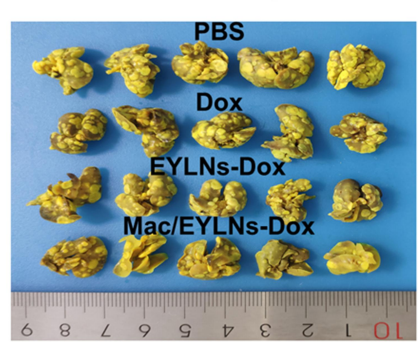

$\mathbf{F}$
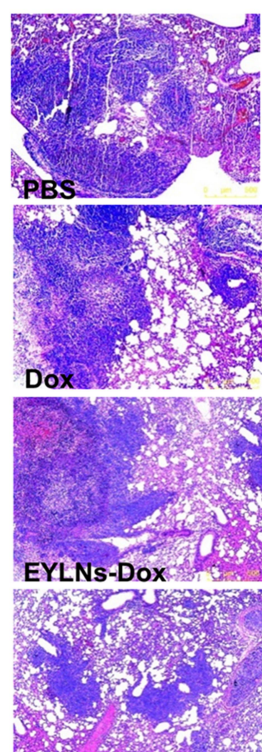

Mac/EYLES-DoX

Figure 5 Therapeutic effects of Mac/EYLNs-Dox on 4TI tumors. Subcutaneous implant 4TI tumor mice were treated with PBS, Dox, EYLNs-Dox and Mac/EYLNs-Dox, (A) tumor growth was recorded every 3 days. (B) Mice were sacrificed 30 days after treatment, tumors were removed and photographed. (C) 4TI lung metastasis model was established and treated with PBS, Dox, EYLNs-Dox and Mac/EYLNs-Dox every 5 days for 5 times, the metastatic tumors were detected by in vivo imaging and the tumor signals were quantified (D). After 5 times treatment, mice were sacrificed and the lungs were removed, stained with and photographed (E), the pathology of lungs was analyzed by HE staining $(\mathbf{F}) .{ }^{*} p<0.05, * * p<0.01$. Scale bar: $500 \mu \mathrm{m}$.

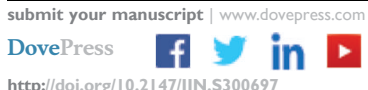

http://doi.org/10.2147110N.S300697
International Journal of Nanomedicine 2021:16 237-238

(c) (i) (5) 2021 Dove Medical Press. This work is published and licensed by Dove Medical Press Limited. The full terms of this license are available at https://www.dovepress.com/ Cerms.php and incorporate the Creative Commons Attribution - Non Commercial (unported, v3.0) License (http://creativecommons.org/licenses/by-nc/3.0/). By accessing the work you hereby accept the Terms. Non-commercial uses of the work are permitted without any further permission from Dove Medical Press Limited, provided the work is properly attributed. For permission for commercial use of this work, please see paragraphs 4.2 and 5 of our Terms (https://www.dovepress. com/terms php). 


\section{Publish your work in this journal}

The International Journal of Nanomedicine is an international, peerreviewed journal focusing on the application of nanotechnology in diagnostics, therapeutics, and drug delivery systems throughout the biomedical field. This journal is indexed on PubMed Central, MedLine, CAS, SciSearch ${ }^{\circledR}$, Current Contents ${ }^{\circledR} /$ Clinical Medicine,
Journal Citation Reports/Science Edition, EMBase, Scopus and the Elsevier Bibliographic databases. The manuscript management system is completely online and includes a very quick and fair peer-review system, which is all easy to use. Visit http://www.dovepress.com testimonials.php to read real quotes from published authors. 